\title{
Momentum, December 2007
}

Population Council

Follow this and additional works at: https://knowledgecommons.popcouncil.org/ series_newsletters_momentum How does access to this work benefit you? Let us know!

\section{Recommended Citation}

"Momentum, December 2007," newsletter. New York: Population Council. 

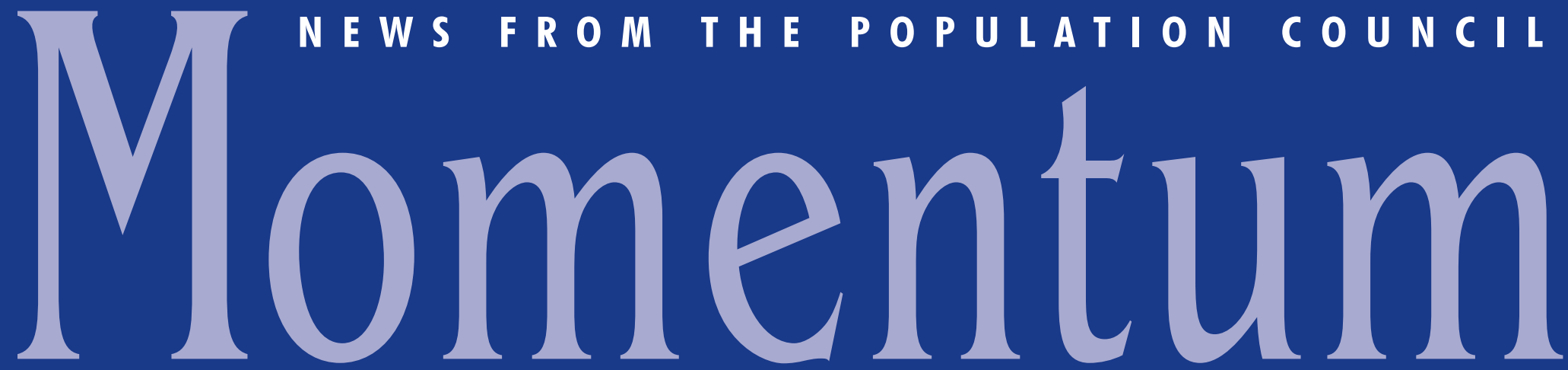

DE C E M B E R 20007

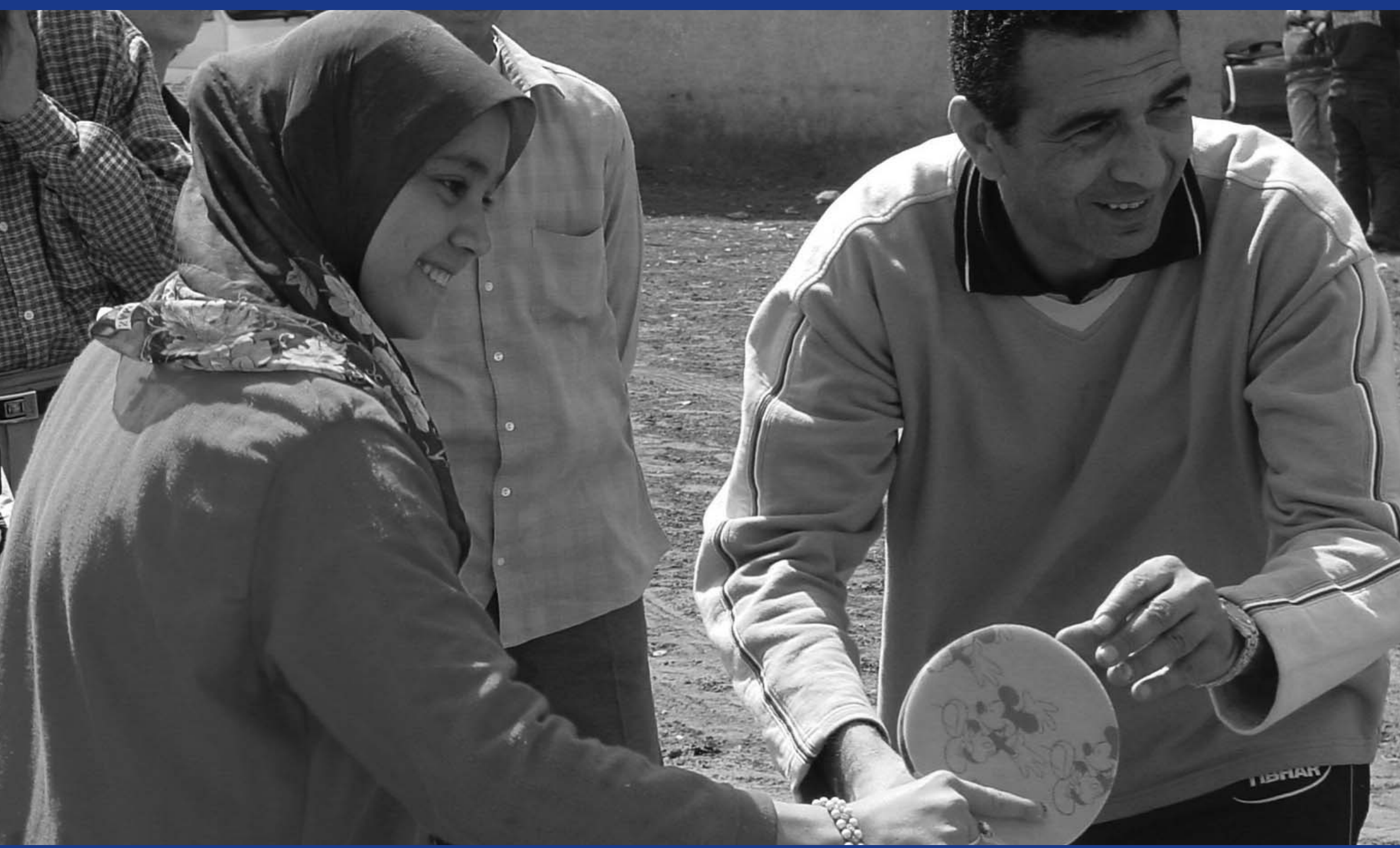

Egyptian girls get their first taste of sports through Ishraq, a program that also gives them safe meeting spaces,

a second chance at education, and more. See "Providing new opportunities to adolescent girls in Egypt," page 2.

\section{N S I D E}

Council featured on PBS NOW

Innovative contraceptive gels

Council awarded USAID contracts

Building the evidence base for effective policy decisions

Providing new opportunities to adolescent girls in Egypt and sprays enter clinical testing HIV and AIDS: Identifying programs that work

Taking action in Darfur

Sandra García honored

Developing young leaders in South Africa

Public health experts join Board Year-end giving

Helping to improve education in Malawi

Council mourns the loss of a scientific leader

Change in Vietnam

Bixby fellowships initiated 


\section{Council featured on PBS NOW}

$\mathrm{T}$ he Population Council's work with Mayan girls in Guatemala was highlighted in October on the PBS weekly newsmagazine NOW. Senior correspondent Maria Hinojosa traveled to Guatemala, India, and Niger to meet child brides and document the campaign the Council and other organizations are conducting to end child marriage. Only 14 percent of rural Mayan

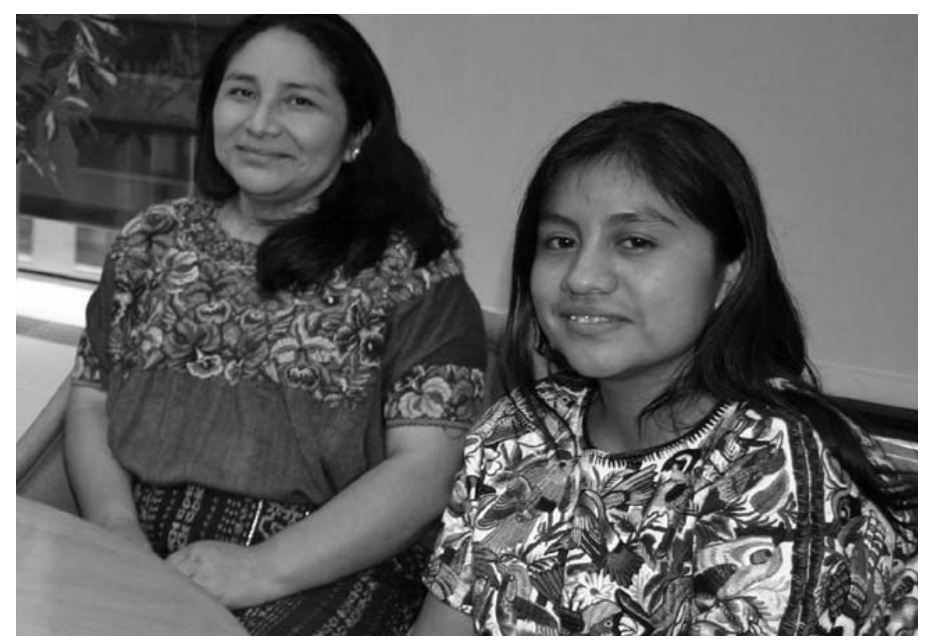

Guatemalans Marta Julia Ruiz, left, and Rosa Lacan appeared in a PBS documentary that featured the Council's work with Mayan girls.

adolescent girls have completed primary school. Leaving school early sets in motion an all-too-common script: early marriage, frequent unsafe pregnancies, social isolation, arduous domestic and childcare burdens, limited decisionmaking power within and outside the family, and gender-based violence.

The one-hour film, "Child Brides: Stolen Lives," features Council researcher Marta Julia Ruiz discussing the Council's efforts to enable Guatemalan girls to reach their full potential. A participant and now a program mentor, Rosa Lacan, was also featured, speaking to girls and mothers in her village about the goals of increasing girls' social support networks, connecting them with role models and mentors, and providing training so they can participate fully in the economic and civic life of their communities.

Ruiz and Lacan and other members of the Council's Guatemala team, Kelly Hallman and Eva Roca, joined Hinojosa in NewYork for a screening of the documentary at the Council's headquarters and participated in an informal discussion and question-and-answer session with more than 60 representatives of colleague organizations and donors. More information about the Council's program to end child marriage in Guatemala and other countries can be found at www.popcouncil.org/ta/mar.html.

\section{Council awarded USAID contracts}

$\mathrm{T}$ he Population Council was recently awarded two United States Agency for International Development contracts under the Population, Health and Nutrition Technical Assistance and Support Contract (TASC3). The Council therefore is on a short list of prequalified firms that are eligible to provide technical assistance and research to United States missions overseas that are supporting work in areas such as maternal and child health, family planning, and HIV and AIDS.

“These awards are important both as a means of funding future research and as an acknowledgment of the depth and breadth of the Council's expertise," says the Council's president, Peter J. Donaldson. "We are gratified to have been selected, and we are excited by the opportunities now available to us."

\section{BUILDING THE EVIDENCE BASE FOR EFFECTIVE POLICY DECISIONS}

0 ne-and-a-half billion young people in developing countries are preparing for adulthood. How well they-the largest generation in historynavigate the transition will have a tremendous impact on their own countries and, by extension, the world. Knowledge about the challenges they face will be crucial to any efforts to help them realize their potential. Historically, however, research has tended to treat adolescents as a more-or-less homogeneous group comprising children as young as 10 to youths as old as 24 . Typical notions of adolescents - that they live at home, go to school, do not work, and are not married-do not apply to a significant proportion of adolescents in developing countries.

The good news is that, when high-quality schooling is accessible and educational experiences are positive, even the most disadvantaged children can become successful adults. The Council's multidisciplinary research on adolescents, initiated more than 15 years ago, is providing policymakers in countries as diverse as Bangladesh, Egypt, Ethiopia, Guatemala, India, Kenya, Mali, Mexico, and Nigeria with the accurate and specific knowledge they need to foster healthy, safe, and productive transitions to adulthood, especially for girls. Generally destined for a life of poverty, illiteracy, early marriage, high fertility, and poor health, girls from the very earliest stages of adolescence are most in need of targeted assistance.

\section{Providing new opportunities to adolescent girls in Egypt}

O ut-of-school girls are the most disadvantaged adolescents in rural Upper Egypt. Compared with girls attending school, they are more likely to be engaged in poorly paid farm work and be married early. They also are at greater risk for early childbearing and poor pregnancy outcomes. The Ishraq ("Enlightenment") program was created to transform girls' lives by providing them with safe meeting places, giving them a second chance for education, and helping them acquire the skills to participate in the local economy.

Initially, Ishraq sought to enroll 50 girls from each of four rural villages in one of the country's poorest regions. However, in response to considerable interest and growing waiting lists, the pilot program, launched in August 2001, ultimately accommodated 278 girls. More than 900 girls have participated since then. As the program expands, it will be introduced in as many as 30 villages in Egypt's three most impoverished and conservative governorates. With about 50 girls recruited into the program per village, followed by annual recruitments in each of the 30 villages, the Council and its partners hope to reach about 3,000 girls and their families, while building local capacity to sustain the program over the long run.

Council researchers have evaluated Ishraq rigorously from its inception (see box). Ishraq is one of ten

\section{MEASURABLE RESULTS}

The statistics document the impact of the Ishraq program on the lives of outof-school girls in Upper Egypt:

- 92 percent of participants who took the government's literacy exam passed.

- 62 percent have entered school (a figure expected to rise when the eligibility age is lowered from 13 to 11).

- 72 percent were against the practice of female genital cutting/mutilation after one year of participation in the program.

- 94 percent said they enjoyed playing sports (like table tennis, see cover). At the beginning of the project, less than two percent had ever participated in sports.

- 50 percent have joined a local club or association since participating in the program. interventions implemented and documented by the Population Council in a five-year project on "Adolescent Girls' Transition to a Safe, Self-Determined, and Productive Adulthood," funded by the UK Department for International Development. Its success has led to preparation for scaling-up the program nationwide with the support of Egypt's National Council for Youth and the National Council for Childhood and Motherhood. The success of Ishraq is prompting the Council, with strong encouragement from the Government of Yemen, to seek the resources to adapt the model and pilot it in Yemen. 


\section{Developing young leaders in South Africa}

O urrent approaches to disseminating information to young people in South Africa about reproductive health and HIV transmission prevention are not working. More than one-third of the country's young women are becoming pregnant as teenagers, 17 percent of 15 to 24-year-old females are living with HIV (versus 4 percent of males in the same age group), and the ratio of new HIV infections among young people is running eight-to-one female-to-male.

To help reverse these trends, the Population Council is partnering with local civil society organizations and researchers in South Africa in a program that builds social networks and support and provides information and skills for better reproductive and sexual health; HIV prevention, treatment, and care; and the exercise of individual economic, social, and civil rights. The program format is designed to be relevant to adolescents' needs and interests. The evidence so far suggests that young people accept key health messages more frequently when they are combined with activities such as interactive skills building and discussion of how social and economic vulnerabilities relate to health behaviors. All of the program activities are geared toward building critical skills for accessing and using information important to young people's future well-being. Council researchers are now seeking funding to replicate this approach in a program targeted to 16 to 18-year-olds, encouraging the graduates of the first program to lead the second.

Ample evidence shows that the program will succeed in appealing to the targeted group. Younger siblings and friends of the pilot-program participants, who wanted the information and skills the program offers, began meeting on their own after school and on weekends. Program staff took on the extra work of mentoring these younger "participants" because of their enthusiasm and selfmotivation.

\section{Helping to improve education in Malawi}

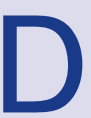
espite being one of the world's poorest countries, Malawi was a pioneer in eliminating primary-school fees in 1994. Since then, the country's school system has experienced an enormous increase in primary-school enrollment-a resounding success in providing access to basic education, but also a tremendous challenge. With limited resources and undertrained teachers, school quality has apparently suffered, and students in primary school are not acquiring the basic skills and competencies they need. The Ministry of Education and other education specialists are seeking information and guidance that will allow them to improve school quality within an exceptionally resource-poor environment. They recognize that without improvements in the

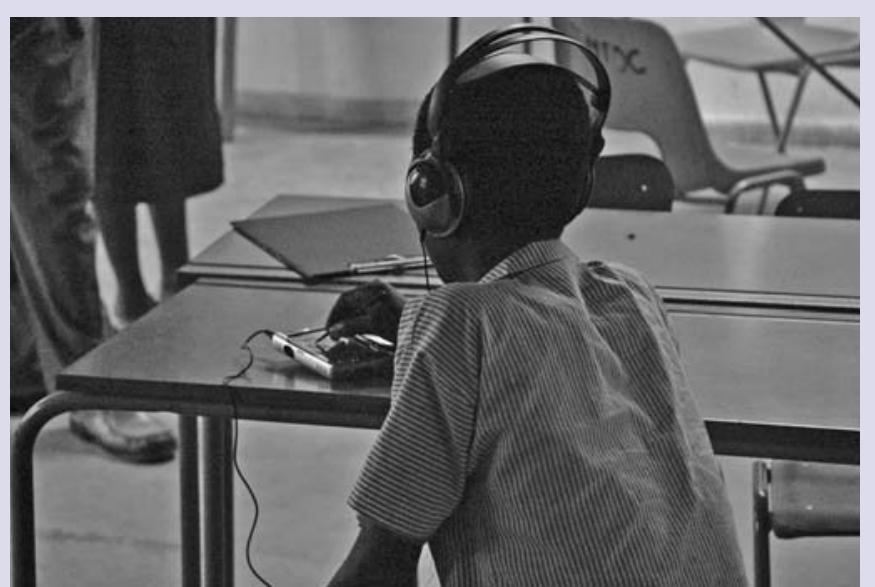

A Malawian student answers questions using a mobile audiocomputerized self-interviewing (ACASI) device. Research suggests that the privacy afforded by the computerized interview encourages more honest answers than are obtained in other types of interviews.

\section{Change in Vietnam}

$\longrightarrow$ ouncil researchers are conducting a household survey and interviews among young people in ethnic minority communities in remote mountain regions of Vietnam, where about one-third of the population is between the ages of 10 and 24. The populace in these areas has not enjoyed the same degree of poverty reduc-

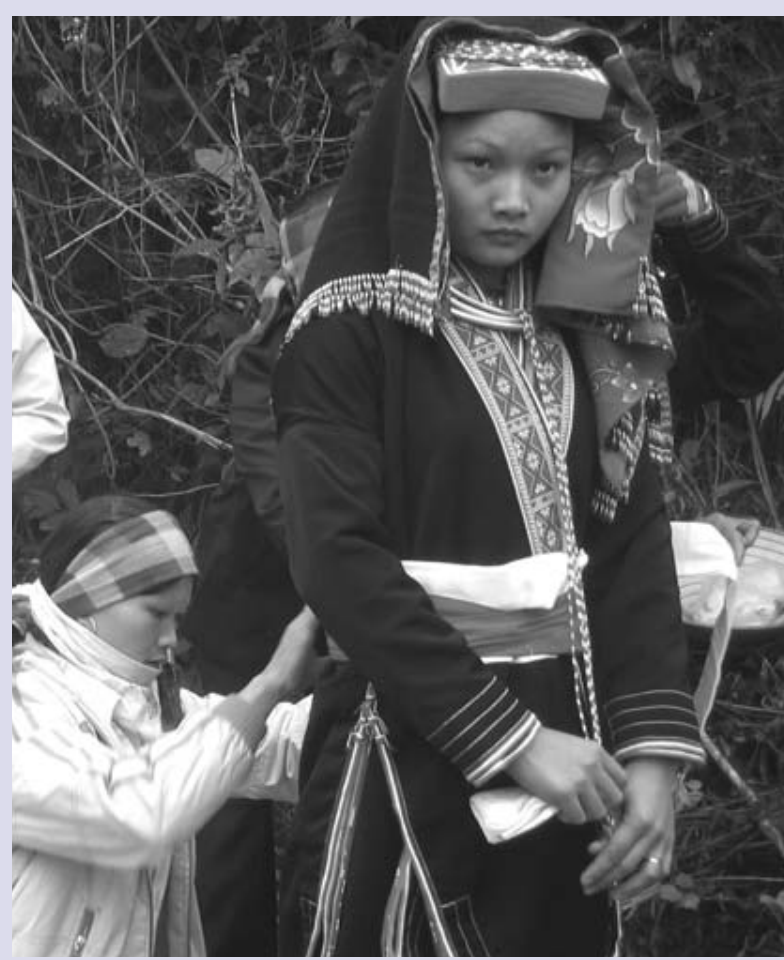

Dao girl, 19 years old, at her wedding in Na Khoan village, Phuong Giao commune-one of the study communities. Marriage still takes place early in the remote areas, and as for many young brides, this marks the first time this young woman will live away from her home community.

tion and improved living standards as the rest of the country, which is benefiting from recent economic growth. The third youth and family survey since 1999, this latest Council collaboration with the Vietnamese government is designed to elicit information about how the government's recent, geographically targeted antipoverty development efforts are affecting young people's decisions about school, work, family formation, and reproductive health. The researchers are seeking to develop strategies that the government can adopt to better address the needs of a vulnerable population living where few opportunities exist. 


\section{Innovative contraceptive gels and sprays enter clinical testing}

$\mathrm{M}$ any women are dissatisfied with their current contraceptive choices. Thirtyone percent discontinue use of reversible contraceptives for method-related reasons within six months of starting to use them, and 44 percent have abandoned their chosen method within a year.

More than 100 million married women in the developing world who do not want to become pregnant are not practicing contraception. Many lack access to reproductive health services and, for many, the current contraceptive options are unsuitable for their day-to-day lives. Young women just entering their reproductive years who want to have small families will need to rely on contraceptives for an average of 30 to 35 years (from their late teens until they are about 50). The current unmet need for contraception, combined with anticipated future need, makes expanding the choice of safe, effective, and inexpensive methods critical.

The Population Council is testing two innovative transdermal delivery systems: a gel product, developed in collaboration with Antares
Pharma of Santiago, Chile, and a spray-on method, produced in partnership with Acrux Limited of Australia. Both products contain Nestorone ${ }^{\circledR}-a$ versatile synthetic progestin similar to the natural hormone progesteronewhich has been studied extensively by Council scientists. Nestorone can be used in rings,

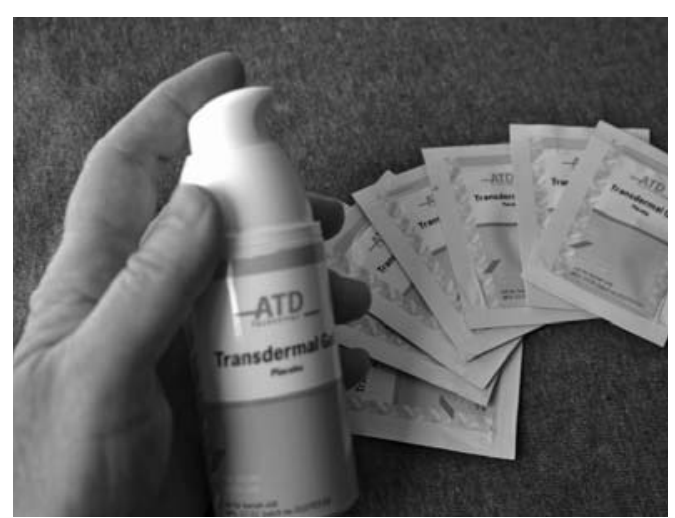

New products would allow women to apply contraceptive spray or gel to a forearm or leg or to the abdomen. patches, gels, and implants and, combined with estrogen or used alone, for contraception or hormone therapy. The spray represents the first non-oral contraceptive developed to deliver natural estrogen in combination with Nestorone. One advantage of this approach is that the risk of venous thromboembolism (blood clots) is four times lower with transdermal delivery than with oral delivery of the compound.

If proven safe and effective, both methods would be affordable, reversible, and easy to use. They are applied to and absorbed through the skin and take advantage of the skin's ability to deliver substances into the bloodstream. Because they are not used orally, both methods are particularly appropriate for use by breastfeeding mothers.

Dose-finding studies of Nestorone delivered via the gel indicate that a sufficient amount of the molecule can be delivered through the skin to inhibit ovulation. Earlier studies showed that the gel is well accepted by women and easy for them to administer.

\section{HIV and AIDS: Identifying programs that work}

$\mathrm{H}$ orizons - a collaboration of six organizations led by the Population Council-designs, implements, and evaluates innovative HIV prevention and treatment strategies. The program runs until mid-2008 and is funded through the United States Agency for International Development.

One goal of Horizons is to prevent HIV transmission from mother to child in sub-Saharan Africa, where the AIDS pandemic continues to devastate individuals, families, and communities. Horizons conducted the first evaluation of the mothers 2 mothers (m2m) program in South Africa, which serves pregnant women and mothers living with HIV. $\mathrm{M} 2 \mathrm{~m}$ is a peer-support program designed to help women accept their HIV status by addressing problems resulting from stigma, and providing critical information to assist HIV-positive women to take steps to safeguard their own and their infant's health.

The evaluation revealed that the program's participants were more likely than nonparticipants to seek and obtain drugs that reduce transmission of HIV to their infants; to make appropriate choices regarding feeding their babies; and to disclose their HIV status to family members. With a proven track record, $\mathrm{m} 2 \mathrm{~m}$ is now expanding to other sub-Saharan African countries in order to serve many more women and infants in need.

Horizons also conducts research among high-risk hard-to-reach, and often neglected populations. One such population, men who have sex with men (MSM), is highly vulnerable to HIV infection, especially in sub-Saharan Africa where governments have been slow to acknowledge the existence of MSM or provide them with information about prevention of HIV transmission and treatment. In Kenya, as in most African countries, sex between men is illegal, which made a recently completed Horizons project for men who sell sex to men in Mombasa, Kenya, especially challenging.
The project's goal was to estimate the number of male sex workers in Mombasa in order to plan effective HIV prevention and treatment programs. Mombasa, with a population of more than one million, is Kenya's second largest city and a major seaport and tourist destination. Bars, nightclubs, brothels, public streets, and parks were among the 77 potential contact locations that the researchers identified. Thirtyseven MSM peer leaders were trained to approach and identify male sex workers. After conducting these activities on consecutive weekends, the researchers concluded that an estimated 739 male sex workers operate in and around Mombasa, a sizable population "who urgently need to be targeted by HIV-prevention strategies." Findings were published in an article entitled, "'Are you on the market?': A capturerecapture enumeration of men who sell sex to men," in the journal AIDS in June 2007.

Following these activities, Horizons and its collaborators conducted a survey of HIV transmission knowledge and sexual practices among male sex workers. Results of the survey informed plans for implementing transmission prevention and other services. Health-service providers and peer educators were trained, and a drop-in center was opened to deliver these services. A follow-up survey is scheduled for late 2007 to gauge whether the services have increased knowledge and altered behaviors among the men who receive them.

Other Horizons projects are also having a positive impact on policies and programs important to those infected or affected by HIV and AIDS. These include a study of adherence to antiretroviral therapy in Mombasa, an evaluation of the Straight Talk massmedia communication program in Uganda, and a study of male gender norms in Brazil and India. For more information, visit the Council's website at www.popcouncil.org/horizons.
Momentum

\section{(1) Population Council}

One Dag Hammarskjold Plaza New York, NY 10017

Phone: 212-339-0500 Fax: 212-755-6052

E-mail: pubinfo@popcouncil.org

www.popcouncil.org

Momentum is a semiannual newsletter of the Population Council. Information may be reproduced without permission, provided it is distributed free of charge and the source is acknowledged. Online at www.popcouncil.org/ publications/momentum/default.htm.

The Population Council is an international, nonprofit, nongovernmental organization that seeks to improve the well-being and reproductive health of current and future generations. The Council conducts biomedical, social science, and public health research in three areas: HIV and AIDS; Poverty, Gender, and Youth; and Reproductive Health. Established in 1952, the Council is governed by an international board of trustees. Its New York headquarters supports a global network of 19 regional and country offices.

Writer Suzie Elliott

Editors Rob 0'Sullivan/Ruth Kalla Ungerer Copyeditors Robert Heidel/Karen Tweedy-Holmes Designers Y. Christina Tse, Mike Vosika

\section{REGIONAL OFFICES}

South and East Asia: New Delhi, India Sub-Saharan Africa: Accra, Ghana West Asia and North Africa: Cairo, Egypt

ISSN 1535-0525

(C) 2007 The Population Council, Inc. Printed in the USA on recycled paper

Photo credits-cover: Nadia Zibani; page 2: Karen Tweedy-Holmes; page 3 (left): Stephen Cao, (right) Bussarawan Teerawichitchainan; page 4: Karen Tweedy-Holmes; page 5: Clinton Global Initiative; page 6: Karen Tweedy-Holmes 


\section{Taking action in Darfur}

$\mathrm{n}$ September, at the annual meeting of the Clinton Global Initiative, the Population Council made a commitment to help end educational disparities for poor children worldwide. As part of this commitment, the Council also accepted an invitation to join the Education Partnership for Children of Conflict, cofounded by actress-activist Angelina Jolie and economist Gene Sperling. Former President Bill Clinton launched the partnership on the first day of the three-day conference, which brings together

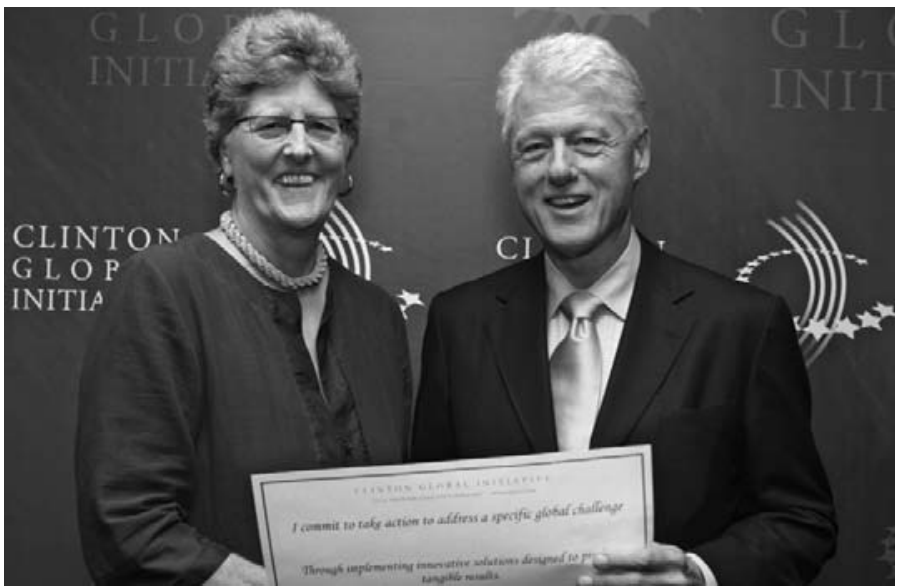

Cynthia B. Lloyd-who represented the Council at the Clinton Global Initiative-joins Bill Clinton in announcing the Council's commitment to action. Lloyd has spearheaded much of the Council's extensive research on education in developing countries and was editor of the seminal 2005 report Growing Up Global: The Changing Transitions to Adulthood in Developing Countries for the National Research Council and the Institute of Medicine of The National Academies. heads of state, development professionals, tions to the world's most pressing challenges, including disparities in education.

The Council, in partnership with the Women's Commission for Refugee Women and Children, will conduct a study of schooling opportunities in the refugee camps of Darfur, Sudan, to determine whether education offers children protection in emergency situations. Researchers will visit the camps to interview children, families, and teachers. The study is being funded through a grant from The John D. and Catherine T. MacArthur Foundation; additional funds are being sought to extend the project from one year to five so that children's individual progress can be tracked over time.

The Population Council has worked with local organizations in Sudan for more than 20 years, and opened a fourperson office in Khartoum this year to enhance cooperation with local professionals and institutions. Other Council projects in Sudan focus on urban poverty and health and on reproductive health issues.
Sandra García honored

0 andra G. García, the Council's director of reproductive health for Latin America and the Caribbean, recently received the Guttmacher Institute's 2007 Darroch Award for Excellence in Sexual and Reproductive Health Research. She was cited for her "research documenting abortion-related knowledge, attitudes, and practices in Mexico" and for her collaboration with "local nongovernmental organizations, universities, professional associations, and the Mexican government" that "played an important role in the country's recent decision to legalize first-trimester abortion." The award also acknowledged her more than 30 peer-reviewed publications on "new reproductive technologies, surveys of women's knowledge about emergency contraception, programs to prevent sexually transmitted diseases among newborns, and innovative methods for measuring abortion incidence." Established in 2005, the biennial award named for Jacqueline E. Darroch, a former senior vice president at Guttmacher, recognizes emerging leaders in the field of sexual and reproductive health.

\section{Three public health experts join Board}

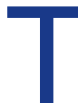

hree distinguished public health professionals have been elected to the PopuIation Council's Board of Trustees.

Wafaa El-Sadr is Professor of Clinical Medicine and Epidemiology at the Mailman School of Public Health and the College of Physicians and Surgeons at Columbia University. She serves as director of Columbia's International Center for AIDS Care and Treatment Programs and the Center for Infectious Disease Epidemiology Research. El-Sadr also maintains a clinical practice and is the chief of the Division of Infectious Diseases at Harlem Hospital. Her research interests focus on the epidemiology, prevention, and treatment of HIV and tuberculosis.

Anna Glasier is director of Family Planning and Well Woman Services and Lead Clinician for Sexual Health for the National Health Service in Lothian, Scotland, and is an honorary professor at both the University of Edinburgh School of Clinical Sciences and Community Health and the Department of Public Health and Policy at the University of London School of Hygiene \& Tropical Medicine. She is a longtime member of the Council's International Committee for Contraception Research.
Anne Pebley is professor and chair of the Department of Community Health Services at the School of Public Health at the University of California, Los Angeles. She joined UCLA from RAND, where she was director of the Population Research Center. Prior to RAND, Pebley spent 14 years at Princeton University as a professor of demography and international affairs. Pebley has also served on the Council's Fellowship Committee.

“Wafaa El-Sadr, Anna Glasier, and Anne Pebley are all accomplished, committed, and richly experienced professionals," says Council President Peter J. Donaldson. "Particularly important at this stage in the Council's evolution, each has a deep, substantive knowledge of our work and its relevance to real-world issues. We are very grateful that they are lending the Council their experience and expertise."

The trustees also appointed Lauren Meserve to the Investment Committee. Meserve is a senior investment officer at the Metropolitan Museum of Art in New York City. She has a certificate in demography, earned while she was a graduate student at Princeton University's Woodrow Wilson School of Public and International Affairs.

\section{YEAR-END GIVING}

In this time of sharing, please make a contribution to the work of the Population Council. You may contribute to the Council's Annual Fund, the pool of unrestricted gifts that we depend on to seed innovation and tackle complex, often controversial issues. Or you may designate your gift to advance the work of one of the Council's three programs: HIV and AIDS; Poverty, Gender, and Youth; or Reproductive Health.

Every gift makes a difference to the lives of the most vulnerable among us. Help a young girl choose education over early marriage through support of the Council's efforts to end child marriage. Help expand access to contraceptives and give first-time parents in India and elsewhere the chance to dote on their newborn child and choose whether and when to have other children. Or help to train an adolescent in South Africa as a mentor to peers who lack information about how to protect themselves from acquiring HIV. These are but a few examples of how your gift can make a difference. Many more can be found at www.popcouncil.org. 


\section{Council mourns the loss of a scientific leader}

$\mathrm{M}$

att Hardy, senior scientist at the Population Council's Center for Biomedical Research, died Sunday, November 4, at home, after running his 12th New York City marathon.

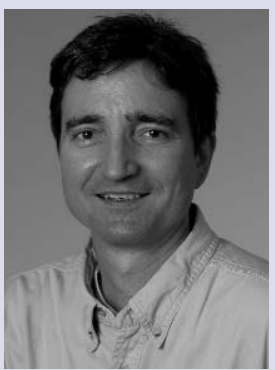

Council president Peter J. Donaldson said, "The Population Council has lost a productive scientist, a supportive colleague, and a dear friend. My deepest condolences go to his wife Dianne, also a scientist at the Center for Biomedical Research, and to his family and friends."

Matt joined the Council in 1991. His research focused on the endocrinology of the male reproductive system. Matt was an expert on Leydig cell function, the cells in the testis that make testosterone. He studied the effects of stress on testosterone secretion, the impact of environmental toxicants on male fertility, and potential new targets for male contraception.

Matt published over 65 papers in peer-reviewed journals and won numerous awards for his research. He served on the editorial boards of several journals, including the Journal of Andrology, of which he was co-editor-in-chief; the Archives of Andrology; and the Biology of Reproduction. He had recently been selected to receive the 2008 Distinguished Service Award of the American Society of Andrology. Matt was an adjunct faculty member at The Rockefeller University, the Weill Medical College of Cornell University, and Sichuan University, China.

Matt was a regular spokesperson for better male contraception-for example, recently discussing the topic on CBS's national Saturday Early Show. Conducting research with enthusiasm and creativity, he was a wonderfully supportive mentor, inspiring other researchers, including many Council fellows.

"He was a passionate supporter of basic research, and its contribution to the Council's mission," Donaldson said. "I valued my conversations with Matt, and respected his judgment. I will remember Matt's energy, commitment, and good will, and will miss him and his good advice very much, as will all who knew him." -

\section{STAY CONNECTED}

We want to be sure all Population Council alumni have the opportunity to stay in touch through Momentum. Contact Ruth Kalla Ungerer, Director of Development, at rungerer@popcouncil.org or 212-339-0515 to share your news or comments about Council projects.

\section{Bixby Fellowships initiated}

$\mathrm{P}$ ostgraduate fellowships fulfill an essential part of the Population Council's mission - training professionals to address population, health, and development issues and expand research capacity in developing countries. During the past five decades, the Council's fellowship programs have provided training for more than 2,500 biomedical, public health, and social science researchers, many of whom have progressed to hold leadership positions in the global health field. Funding for Council fellows is provided by such private foundations as The Fred $\mathrm{H}$. Bixby, the F. M. Kirby, and The Wallace foundations; the United States government; individual donors; and the Council itself, through its unrestricted funds.

A new Fred H. Bixby Fellowship Program was recently launched with the naming of four outstanding fellows and their Population Council staff mentors. The Bixby fellowships offer opportunities for researchers from developing countries to work with experienced mentors in the Council's laboratories and network of offices. Chosen from a field of a dozen exceptional finalists, members of the first class of Bixby fellows come to the Council from China, Egypt, India, and Kenya.

Yunhui Zhang, who received her doctoral degree in 2004, is currently associate professor at the School of Public Health at Fudan University in Shanghai. Yunhui's focus is on environmental health science, and as a fellow she will be studying the damaging reproductive effects of DEHP, a chemical commonly found in cosmetics and used in flexible plastics. Her research will be undertaken in the laboratories of the Council's Center for Biomedical Research in New York, under the auspices of the Reproductive Health program.
Asmaa Elbadawy will complete her doctorate in economics at McMaster University in Ontario, Canada, this year. Her research interests lie in the economics of education, gender, marriage, and the family, with a focus on the Middle East region. She will work in the Council's Cairo office under the Poverty, Gender, and Youth program and will be mentored by Ragui Assaad, regional director, West Asia and North Africa.

Subramaniam Chandrasekhar completed his doctorate in economics at Pennsylvania State University in 2004. $\mathrm{He}$ is now assistant professor of economics at the Indira Gandhi Institute of Development Research in Mumbai, India. His fellowship will focus on the multidimensional aspects of urban poverty, with a focus on Indian slums and the living conditions of adolescents. Chandra will work at the New York headquarters of the Population Council as part of the Poverty, Gender, and Youth program, under the guidance of Mark Montgomery, senior associate.

Francis Onyango finished his doctorate in demography at the University of Pennsylvania in the summer of 2007 and recently returned to Nairobi to begin his fellowship. Francis previously worked as a research trainee at the African Population and Health Research Center in Nairobi, where he studied adolescent sexual and reproductive health behavior and the role of voluntary HIV and AIDS counseling and testing. He will be working at the Council's Nairobi office where, as part of the Reproductive Health program, he will study family planning and emergency contraception. Jill Keesbury and Harriet Birungi, program associates, will be his mentors.

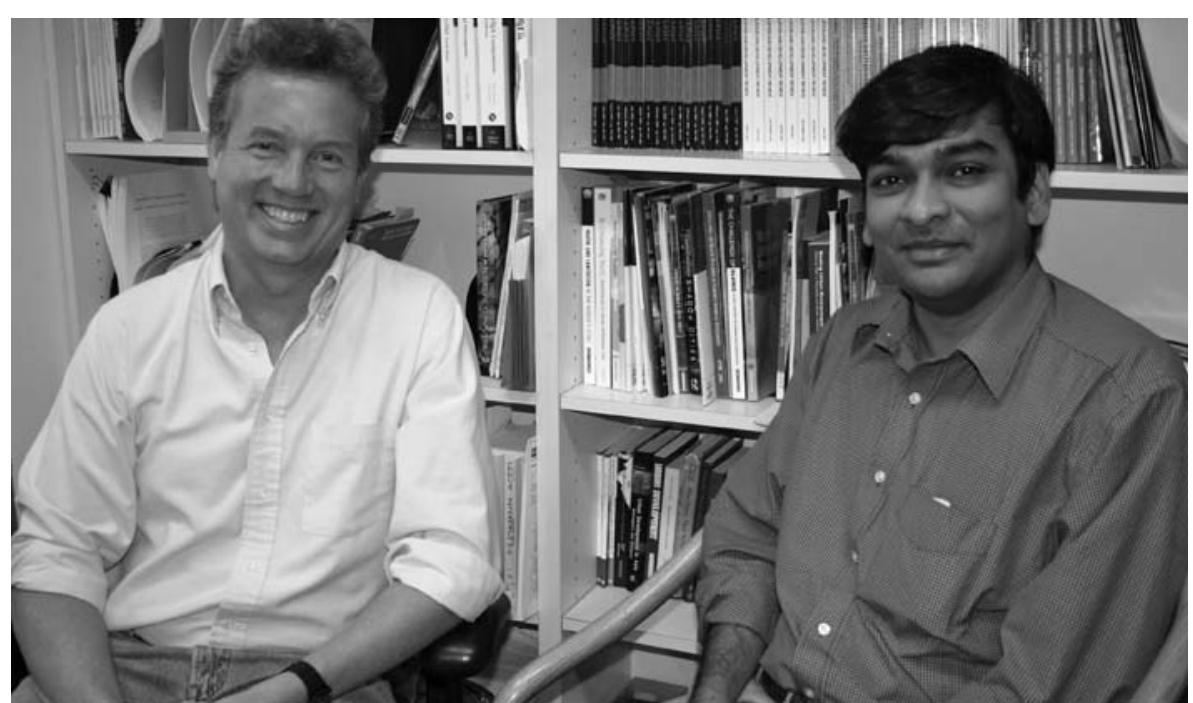

Senior Associate Mark Montgomery advises Subramaniam Chandrasekhar at Council headquarters. 